\title{
EFFECT OF DIFFERENT RATIOS OF LOW PROTEIN FLOUR TO OYSTER MUSHROOM (Pleurotus sajor-caju) POWDER ON THE PHYSICOCHEMICAL PROPERTIES AND SENSORY ACCEPTABILITY OF EDIBLE TABLESPOON
}

\author{
AU JEE YUAN ${ }^{\mathrm{A}}$ AND FARIDAH YAHYA ${ }^{\mathrm{B}^{*}}$ \\ ${ }^{\text {a,b }}$ Faculty of Fisheries and Food Science, Universiti Malaysia Terengganu, Kuala Nerus, Terengganu, Malaysia \\ *Corresponding author: faridahy@umt.edu.my
}

\begin{abstract}
The aim of this study was to determine the effect of different ratios of low protein flour to oyster mushroom (Pleurotus sajor-caju) powder on the physicochemical properties and sensory acceptability of edible tablespoon. Fresh grey oyster mushroom was dried in a convection oven at temperature of $55.0^{\circ} \mathrm{C} \pm 2.0^{\circ} \mathrm{C}$ for $20 \mathrm{~h}$ prior to the grinding process. The low protein flour (LPF) was then incorporated with oyster mushroom powder (OMP) at different ratios of 100:0, 96:4, 92:8, $88: 12$ and 84:16, before being with vegetable oil, sugar, egg white and water in formulating the edible tablespoon. The proximate analyses were carried out in triplicate for calorie content, colour profile, hardness value and morphological structure of edible tablespoon. This study revealed that with decreasing LPF and increasing OMP in the formulation, the ash content (1.24\% to $1.92 \%)$, crude fat content $(8.98 \%$ to $10.40 \%)$ and fiber content $(0.13 \%$ to $1.24 \%)$ were observed to have increased as well as the hardness value $(2042.03 \mathrm{~g}$ to $2844.57 \mathrm{~g})$ and pore's size of the morphological structure of edible tablespoon. However, the carbohydrate content $(78.64 \%$ to $75.56 \%)$ significantly decreased ( $p>0.05$ ) together with $L^{*}$ value (from 68.47 to 61.71 ) when the decrease was in the the percentage of LPF and an increase the percentage of OMP. The calorie content, moisture content and protein content of edible tablespoon were not significantly $(p>0.05)$ affected by different ratios of LPF to OMP. The edible tablespoon formulated with up to $8 \%$ of OMP was accepted by the sensory panelists but further increase in OMP addition significantly decreased the degree of likeness in terms of colour, odour, taste and overall acceptability of edible tablespoon. This study suggested that oyster mushroom edible tablespoon could be potential alternative disposable cutlery which will help to reduce the use of huge amount of non-biodegradable materials for environmental conservation.
\end{abstract}

Keywords: Oyster mushroom powder, edible tablespoon, morphological structure, physicochemical properties, sensory acceptability

\section{Introduction}

Bakery items are preferred and consumed by nearly all levels of society (Herken et al., 2017). Their ready to eat nature, affordable cost, good nutritional quality, availability in different taste and long shelf-life make them popular and widely acceptable by the public (Ashoush \& Gadallah, 2011). The edible tablespoon is made from cookies like dough composed of low protein flour, oil, water and a little amount of flavouring agent and then moulded into a tablespoon shape. The development of edible tablespoon is to reduce the use of huge amounts of non-biodegradable materials which has created a global issue on handling the waste which would cause devastation of the ecosystem and environment. Among the food wastes, 34\% are from the plate wastes which include the single-use cutleries, plastic or laminated paper plates and cups (Fieshchi \& Prestato, 2017).

Mushrooms, widely used as food ingredients are incorporated with various food products due to availability and also their relatively easy conditions (Wan Rosli et al., 2011). Oyster mushrooms are rich in nonstarchy carbohydrates, with high content of dietary fiber, moderate quantity of proteins which include most of the amino acids, minerals and vitamins (Croan, 2004). It is also found that the oyster mushrooms are low in energy, fat and sodium and thus often categorized as ideal and healthy food for people with high 
blood cholesterol, hypertension and also atherosclerosis (Dunkwal et al., 2007; Manzi et al., 2004). Oyster mushrooms are highly perishable and have a short shelf life (Wakchaure et al., 2010). Therefore, they must be processed to maintain nutritional quality to prolong their shelf life (Walde et al., 2006). Drying is one of the oldest preservation methods and applicable to the storage of mushrooms (Wojdyło et al., 2016). The powdered form of dried mushroom is suitable in the fortification of baked products like breads and biscuits (Farzana \& Mohajan, 2015). Some previous studies have been done on the incorporation of oyster mushroom powder into chicken patty (Wan Rosli \& Solihah, 2014), cinnamon biscuits (Ng et al., 2017) and mushroom biscuits (Wan Rosli et al., 2012), but the incorporation into edible tablespoon is still at an early stage. Hence, the current study aimed to determine the effect of different ratios of low protein flour to oyster mushroom (Pleurotus sajor-caju) powder on the physicochemical properties and sensory acceptability of edible tablespoon.

\section{Materials and Methods}

Fresh grey oyster mushrooms (Pleurotus sajorcaju) were obtained from Wafa Spora Enterprise in Marang, Terengganu, Malaysia. Harvested fresh mushrooms were in a maturity of 1 to 3 days with moisture content of more than $80 \%$ as analyzed by moisture analyser (MA100 Sartorius, German). The other ingredients for edible tablespoon such as sugar, eggs, vegetable oil, low protein flour, milk powder, baking soda and baking powder were purchased from the local grocery at Kuala Nerus, Terengganu.

\section{Preparation of oyster mushroom powder}

The preparation ofOMPwas carried outaccording to the modification method from Martínez-Soto et al. (2001). The oyster mushrooms were first washed to remove dirt and soil and then soaked in $1 \%$ of sodium metabisulphite (SMS) solution at room temperature for $10 \mathrm{~min}$. The SMS solution was used to preserve the colour of the oyster mushrooms during drying. After soaking, the excess water was drained and squeezed from the mushrooms to shorten the drying process. Then, the mushrooms were sliced into thin pieces and put on a drying tray and wrapped with aluminium foil. The mushrooms were dried in a convection oven at temperature of $55.0^{\circ} \mathrm{C} \pm$ $2.0^{\circ} \mathrm{C}$ for $20 \mathrm{~h}$. The moisture content of the dried mushrooms was checked at an acceptable range of $12.0 \pm 3.0 \%$ prior to grinding process. Dried mushrooms were then ground using an electric blender (Panasonic MX-337, Malaysia) to obtain the powder form and the oyster mushroom powder had to undergo the sieving process using a sieve shaker (Retsh AS 200, German) at a range of $125-500 \mu \mathrm{m}$. The mushroom powder was then sealed in a high-density polypropylene (HDPE) bag and wrapped with aluminium foil to prevent moisture absorption and kept under temperature $4.0 \pm 1.0^{\circ} \mathrm{C}$, away from light source (Ajayi et al., 2015).

\section{Preparation of Oyster Mushroom Edible Tablespoon}

The edible tablespoons were made from hardbiscuit dough which was shaped and placed onto the back of a steel tablespoon to replicate the tablespoon shape. The basic formulation of edible tablespoon included water, sugar, egg white, vegetable oil, milk powder, baking soda, baking powder and different ratios of LPF to OMP. Sugar and water were mixed together at low heat until the sugar was dissolved. The sugar solution was let to cool $\left(50.0 \pm 2.0^{\circ} \mathrm{C}\right)$ and then vegetable oil at room temperature was added and mixed thoroughly before adding in the egg white. All the dry ingredients were mixed and sieved into the mixture to form a dough. The dough was then let to rest for $30 \mathrm{~min}$ and then the dough was sheeted into $0.5-0.7 \mathrm{~cm}$, cut and shaped it accordingly onto the back of a steel tablespoon. Meanwhile, the oven was first pre-heated at $160^{\circ} \mathrm{C}$ for $10 \mathrm{~min}$ and the edible tablespoons were baked for $10 \mathrm{~min}$ and $30 \mathrm{~s}$ and then turned to bake for another $10 \mathrm{~min}$ and $30 \mathrm{~s}$. 


\section{Proximate analysis of edible tablespoon}

The edible tablespoons with different ratios of LPF to OMP were analysed for their moisture, ash, crude fat, crude protein, crude fiber and carbohydrate content according to the standard method (AOAC, 2000) and the analyses were performed in triplicate.

\section{Physical analysis of edible tablespoon}

\section{Determination of calorie content}

The calorie content of the edible tablespoon was measured using bomb calorimeter AC350 (LECO, USA). The oyster mushroom edible tablespoon was crushed into tiny pieces and weighted into $1 \mathrm{~g}$ in order to determine its heat of combustion which equals to the calorie content. The heat of combustion of the sample was calculated using the formula:

$$
\text { Calorie content }(\mathrm{cal} / \mathrm{g})=\left[\frac{C \times \Delta T-\text { wire burned }(\mathrm{cm})(\text { heat per } \mathrm{cm})}{\text { weight of sample }(\mathrm{g})}\right] \text {. }
$$

Where;

$\mathrm{C}=$ Heat capacity of water

$\Delta \mathrm{T}=$ Temperature change

\section{Determination of colour profile}

The determination of colour of the oyster mushroom edible tablespoon was performed by using the colorimeter (Minolta Co., Type CR 300, Japan). The colour of edible tablespoon was presented in the CIE system of $\mathrm{L}^{*}, \mathrm{a}^{*}$ and $b^{*}$ value.

\section{Determination of hardness value}

The TA.XT. Plus Texture Analyser (Stable Micro System Ltd., UK) was used to determine the hardness value of oyster mushroom edible tablespoon according to Woody, (2003). The curved part of the edible tablespoon was put on the support spaced at $30 \mathrm{~mm}$ apart. The pre-test speed was set to $2.5 \mathrm{~mm} / \mathrm{s}$ until $20 \mathrm{~g}$ force detected and then continued down $15 \mathrm{~mm}$ through the curved part of the edible tablespoon at $1.0 \mathrm{~mm} / \mathrm{s}$. The probe withdraws at $10.0 \mathrm{~mm} / \mathrm{s}$. The load cell used was $5 \mathrm{~kg}$. The maximum force and the distance to break off the sample was recorded.

\section{Measurement of morphological structure}

The curve part of the oyster mushroom edible tablespoon was cut into $2 \mathrm{~cm} \times 0.5$ $\mathrm{cm}$ of maximum length and thickness. The morphological structure observation was performed by using Scanning Electron Microscope (SEM) (JEOL JSM 6360LA, Japan). Before loading, the sample was subjected to SEM specimen stubs with diameter of $12.5 \mathrm{~mm}$ by using a double-sided adhesive tape. Then, the sample was first coated with $30 \mu \mathrm{m}$ gold by auto fine coater (JEOL JFC-1600, Japan). The coated sample was then observed by analytical SEM with $5.0 \mathrm{kV}$ potential under $35 \times$ magnification to determine the granule size and diameter.

\section{Sensory evaluation}

Five formulations of freshly baked edible tablespoon were presented to 30 untrained panellists of students and staff of Universiti Malaysia Terengganu to evaluate the sensory acceptability in terms of colour, hardness, taste, odour, suitability as a tablespoon and overall acceptance using 7-point of hedonic scale of acceptance test. Five samples were labelled with three digits random number and arranged accordingly by random permutation. All the panellists were provided with a carrier sample of a small bowl of fried rice in order to test the suitability of the edible tablespoon.

\section{Statistical analysis}

All data were presented as mean value and standard deviation. Significant difference among the means were determined using one-way analysis of variance (ANOVA) and followed by post-hoc test of Fisher's Least Significant Difference (LSD) at $\mathrm{p}<0.05$ using Statistical Package for Social Sciences (SPSS) software.

\section{Results and Discussion}

\section{Proximate composition of edible tablespoon}

The proximate composition of oyster mushroom edible tablespoon with different ratios of low protein flour (LPF) to oyster mushroom powder 
(OMP) is shown in Table 1. As can be seen, there was no significant difference $(p>0.05)$ in moisture content of all edible tablespoons which might be due to baking conditions, temperature, air humidity and moisture absorption of ingredients. The amount of moisture content in biscuit is a crucial indicator of the quality of the biscuit especially on the sensory, textural and microbial properties of final products (Ahlborn et al., 2005). However, interesting to note that there was a significant increasing trend of ash content from $0 \%$ of OMP to $16 \%$ of OMP addition in edible tablespoon where the control sample $(0 \%$ of OMP) was reported to have obtained the least amount of ash content (1.24 $\pm 0.19 \%$ ) while $16 \%$ OMP edible tablespoon has the highest ash content $(1.92 \pm 0.22 \%)$. The result was in line with oyster mushroom incorporated with cinnamon biscuit $(\mathrm{Ng}$ et al., 2017) and butter biscuits (Wan Rosli et al., 2012). Muyanja et al. (2014) revealed that OMP obtained a high amount of ash content $(7.00 \%)$ at dry basis. This study suggested that ash and mineral content would not be lost during baking process.

Table 1 shows that the fat content of edible tablespoon was only significantly affected by the addition of high amount of OMP at $16 \%$. This result agreed with the fat content of cinnamon biscuits (Ng et al., 2017). However, an unexpected result was found that protein content of edible tablespoon was not affected by different ratios of LPF to OMP. Gothandapani et al. (1997) reported that pre-treatment of oyster mushroom with chemicals (1\% SMS solution) prior to the drying process could lead to protein denaturation which stopped its browning activity and reduced the percentage of free amino acid in the oyster mushroom. In addition, high temperature of baking at $160^{\circ} \mathrm{C}$ might also increase the risk of losing protein (Tolera \& Abera, 2017). As expected, a significant increasing trend was found on the fiber content of the oyster mushroom edible tablespoon (Table 1) due to the rich amount of fiber in oyster mushroom in nature (Cheung, 2013). The huge difference of fiber content of LPF $(0.30 \%)$ and OMP $(7.90 \%)$ has reported by Okafor et al., (2012) also could be the reason in the increase of the fiber content of edible tablespoon with the addition of OMP. The carbohydrate content of edible tablespoon was significantly $(\mathrm{p}<0.05)$ decreased with addition of $0 \%$ to $16 \%$ of OMP. Farzana and Mohajan, (2015) also reported that the carbohydrate content gradually decreased with the increase in the supplementation of soy flour in making biscuits. The decrease could be due to the low carbohydrate content of OMP as compared to LPF in nature.

\section{Calorie content of edible tablespoon}

As can be seen in Table 1, there was no significant difference $(p>0.05)$ on calorie content among five formulations of oyster mushroom edible tablespoon, ranging from $4456.53 \mathrm{cal} / \mathrm{g}$ to $4659.43 \mathrm{cal} / \mathrm{g}$. According to Verma and Singh (2017), oyster mushroom is low in fat, carbohydrate and calories. The incorporation of OMP can help in the enrichment of the nutrient density of the biscuit while maintaining the biscuit calories without raising it (Farzana and Mohajan, 2015).

\section{Colour profile of edible tablespoon}

Table 2 shows the colour profile of edible tablespoon with different ratios of LPF to OMP. The $\mathrm{L}^{*}$ value decreased significantly $(\mathrm{p}<0.05)$ while the value of a* increased and no significant difference $(p>0.05)$ was found in $b^{*}$ value with increasing percentage of OMP in edible tablespoon formulation. These results were in a good agreement with the findings of Majeed et al. (2017) and $\mathrm{Ng}$ et al. (2017) on the $\mathrm{L}^{*}$ value of bakery products. The darker colour of edible tablespoon was due to natural grey colour of oyster mushroom (Majeed et al., 2017) as well as due to caramelization of sugar and Maillard reaction which promote the starch and protein degradation during the baking process at high temperature (Alobo, 2001).

\section{Hardness value of edible tablespoon}

Hardness of edible tablespoon gradually increased from $0 \%$ to $16 \%$ of OMP incorporation and the value obtained ranged from $2042.03 \mathrm{~g}$ to $2844.57 \mathrm{~g}$ in which control formulation had the lowest hardness value $(2042.03 \mathrm{~g} \pm 92.99$ g) while the $16 \%$ of OMP edible tablespoon obtained the highest ones $(2844.57 \mathrm{~g} \pm 111.48$ g). High amount of fiber content in oyster mushroom (Maray et al., 2018; Tolera and 
Abera, 2017) contributed to produce water absorbing properties which can reduce the extensibility of dough and leads to an increase in the hardness value of the product.

\section{Morphological structure of edible tablespoon}

The picture of oyster mushroom edible tablespoon and the SEM micrograph are shown in Figure 1 and Figure 2 respectively. The cell diameter of starch granule of edible tablespoon was observed to increase with increasing percentage of OMP in the formulation (Figure 2 ). This result was in contrast with the previous study in oyster mushroom biscuit at which an increase of OMP reduced the diameter of the starch granule of the biscuits ( $\mathrm{Ng}$ et al., 2017). The difference in the cell diameter was mainly caused by the difference in gluten formation and starch gelatinization (Herken et al., 2017). In addition, it was noticed that the dietary fiber component of OMP embedded in the biscuits affected the starch granule structures, making them irregularly shaped ( $\mathrm{Ng}$ et al., 2017). Besides, it could be explained that the reaction of baking powder and baking soda could interrelate with the irregular size and formation of gas cells in the baking process of edible tablespoon.

\section{Sensory acceptability of edible tablespoon}

The mean scores of sensory acceptability of edible tablespoon with different ratios of low protein flour to oyster mushroom powder is shown Table 3. There were significant differences $(p<0.05)$ found on sensory acceptability of colour, odour, hardness, taste and overall acceptability except for the suitability as a tablespoon between control sample and edible tablespoon with high percentage of $12 \%$ to $16 \%$ of OMP addition. Besides, an addition of up to $8 \%$ of OMP in the formulation did not have any significant difference $(p>0.05)$ with the control sample in any of the sensory attributes.

In terms of colour, odour and taste acceptability of edible tablespoon, there was no significant difference observed until up to $8 \%$ of OMP incorporation. Subsequent increase of OMP to $12 \%$ led to a significant drop in the respective attribute acceptability of the edible tablespoon. This may due to the fact that panellists did not like a darker product which correlated with low in $\mathrm{L}^{*}$ value when increasing the percentage of OMP in the formulation caused the unattractive dull appearance as well as unpleasant aroma and taste to the final product. The mean score of hardness acceptability was found to decrease with increased the percentage of OMP (Table 3). This result was also evidenced in the mushroom-wheat composite flours where Bello et al. (2017) reported that the higher the incorporation of OMP, the harder the biscuits thus lead to a downfall in the mean score of crispiness acceptability.

This study, a 7 point of hedonic scale used for acceptance test and score 1 refers to dislike extremely and score 7 refers to like extremely and all formulations were accepted by the panellists as the mean score obtained that was above 4.00 for overall acceptability. Control sample showed the highest mean score of $5.67 \pm 1.21$ which is significantly different $(p<0.05)$ to the $12 \%$ and $16 \%$ incorporation of OMP in edible tablespoon. The panellist overall acceptability dropped significantly when OMP incorporated was more than $8 \%$. The result was similar to the wheat-mushroom composite flour biscuits in which $5 \%$ incorporation of OMP obtained the highest overall acceptability (Bello et al., 2017).

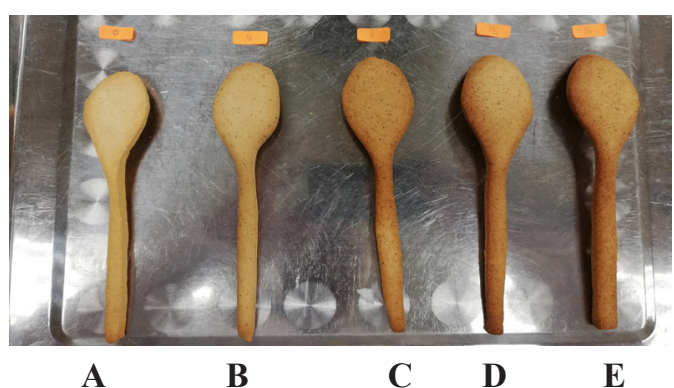

Figure 1 Picture of oyster mushroom edible tablespoon

A-Edible tablespoon with $100 \% \mathrm{LPF}$ and $0 \%$ of OMP (control sample)

B-Edible tablespoon with $96 \%$ LPF and $4 \%$ OMP

C-Edible tablespoon with $92 \%$ LPF and $8 \%$ OMP

D-Edible tablespoon with $88 \%$ LPF and 12\% OMP

E-Edible tablespoon with $84 \%$ LPF and 16\% OMP 
Table 1: Mean value ( $\mathrm{n}=3$ ) of proximate composition and calorie content of edible tablespoon incorporated with different ratios of low protein flour (LPF) to oyster mushroom powder (OMP)

\begin{tabular}{cccccccc}
\hline & Moisture & Ash & Fat & Protein & Fiber & Carbohydrate & Calorie \\
\hline A & $3.02 \pm 0.73^{\mathrm{a}}$ & $1.24 \pm 0.19^{\mathrm{c}}$ & $8.98 \pm 0.69^{\mathrm{b}}$ & $7.75 \pm 0.17^{\mathrm{a}}$ & $0.13 \pm 0.02^{\mathrm{e}}$ & $78.64 \pm 1.26^{\mathrm{a}}$ & $4456.53 \pm 20.30^{\mathrm{a}}$ \\
B & $2.11 \pm 0.52^{\mathrm{a}}$ & $1.39 \pm 0.14^{\mathrm{bc}}$ & $9.25 \pm 0.85^{\mathrm{ab}}$ & $8.00 \pm 0.33^{\mathrm{a}}$ & $0.38 \pm 0.19^{\mathrm{d}}$ & $78.44 \pm 2.10^{\mathrm{a}}$ & $4474.63 \pm 64.75^{\mathrm{a}}$ \\
& & & & & & & \\
C & $2.38 \pm 0.67^{\mathrm{a}}$ & $1.54 \pm 0.16^{\mathrm{bc}}$ & $10.40 \pm 0.61^{\mathrm{a}}$ & $8.02 \pm 0.87^{\mathrm{a}}$ & $0.67 \pm 0.10^{\mathrm{c}}$ & $76.98 \pm 0.66^{\mathrm{ab}}$ & $4565.00 \pm 200.08^{\mathrm{a}}$ \\
D & $3.21 \pm 0.26^{\mathrm{a}}$ & $1.69 \pm 0.14^{\mathrm{ab}}$ & $10.10 \pm 0.61^{\mathrm{ab}}$ & $7.96 \pm 0.20^{\mathrm{a}}$ & $1.05 \pm 0.07^{\mathrm{b}}$ & $76.43 \pm 0.44^{\mathrm{ab}}$ & $4659.43 \pm 346.20^{\mathrm{a}}$ \\
& & & & & & \\
E & $3.26 \pm 0.98^{\mathrm{a}}$ & $1.92 \pm 0.22^{\mathrm{a}}$ & $10.25 \pm 0.34^{\mathrm{a}}$ & $8.04 \pm 0.19^{\mathrm{a}}$ & $1.24 \pm 0.05^{\mathrm{a}}$ & $75.56 \pm 0.99^{\mathrm{b}}$ & $4637.13 \pm 286.88^{\mathrm{a}}$ \\
\hline
\end{tabular}

Means value with different superscript letter in same column are significantly different at $\mathrm{p}<0.05$.

A-Edible tablespoon with 100\% LPF and $0 \%$ of OMP (control sample)

B- Edible tablespoon with 96\% LPF and 4\% OMP

C- Edible tablespoon with 92\% LPF and 8\% OMP

D- Edible tablespoon with $88 \%$ LPF and 12\% OMP

E- Edible tablespoon with 84\% LPF and 16\% OMP

Table 2: Colour profile $(\mathrm{n}=3$ ) of oyster mushroom edible tablespoon with different ratios of low protein flour (LPF) to oyster mushroom powder (OMP)

\begin{tabular}{cccc}
\hline Formulation & $\mathbf{L}^{*}$ & $\mathbf{a}^{*}$ & $\mathbf{b}^{*}$ \\
\hline A & $68.47 \pm 0.99^{\mathrm{a}}$ & $6.53 \pm 0.44^{\mathrm{c}}$ & $25.98 \pm 0.55^{\mathrm{a}}$ \\
B & $67.45 \pm 1.19^{\mathrm{ab}}$ & $7.50 \pm 0.14^{\mathrm{b}}$ & $26.84 \pm 0.28^{\mathrm{a}}$ \\
C & $66.91 \pm 0.94^{\mathrm{ab}}$ & $7.50 \pm 0.40^{\mathrm{b}}$ & $26.80 \pm 1.32^{\mathrm{a}}$ \\
D & $65.54 \pm 1.39^{\mathrm{b}}$ & $7.88 \pm 0.48^{\mathrm{b}}$ & $26.46 \pm 1.03^{\mathrm{a}}$ \\
E & $61.71 \pm 0.87^{\mathrm{c}}$ & $8.72 \pm 0.26^{\mathrm{a}}$ & $27.01 \pm 0.91^{\mathrm{a}}$ \\
\hline
\end{tabular}

Mean values with different superscript letter in the same column are significant different at $\mathrm{p}<0.05$

A-Edible tablespoon with 100\% LPF and $0 \%$ of OMP (control sample)

B- Edible tablespoon with $96 \%$ LPF and 4\% OMP

C- Edible tablespoon with $92 \%$ LPF and $8 \%$ OMP

D- Edible tablespoon with $88 \%$ LPF and $12 \%$ OMP

E- Edible tablespoon with 84\% LPF and 16\% OMP 
Table 3: Mean score $(n=30)$ of sensory acceptability of edible tablespoon with different ratios of low protein flour (LPF) to oyster mushroom powder (OMP)

\begin{tabular}{ccccccc}
\hline & Colour & Odour & Hardness & Taste & $\begin{array}{c}\text { Suitability as a } \\
\text { tablespoon }\end{array}$ & $\begin{array}{c}\text { Overall } \\
\text { acceptability }\end{array}$ \\
\hline A & $5.40 \pm 1.25^{\mathrm{a}}$ & $5.37 \pm 1.25^{\mathrm{a}}$ & $5.13 \pm 1.50^{\mathrm{a}}$ & $5.57 \pm 1.22^{\mathrm{a}}$ & $5.13 \pm 1.57^{\mathrm{a}}$ & $5.67 \pm 1.21^{\mathrm{a}}$ \\
B & $5.67 \pm 1.03^{\mathrm{a}}$ & $5.40 \pm 0.97^{\mathrm{a}}$ & $4.43 \pm 1.61^{\mathrm{ab}}$ & $5.30 \pm 1.24^{\mathrm{a}}$ & $5.13 \pm 1.28^{\mathrm{a}}$ & $5.27 \pm 1.17^{\mathrm{a}}$ \\
C & $5.13 \pm 0.97^{\mathrm{a}}$ & $5.07 \pm 1.20^{\mathrm{ab}}$ & $5.10 \pm 1.32^{\mathrm{ab}}$ & $5.03 \pm 1.33^{\mathrm{ab}}$ & $5.13 \pm 1.31^{\mathrm{a}}$ & $5.37 \pm 1.00^{\mathrm{a}}$ \\
D & $4.20 \pm 1.19^{\mathrm{b}}$ & $4.53 \pm 1.38^{\mathrm{bc}}$ & $4.33 \pm 1.52^{\mathrm{b}}$ & $4.50 \pm 1.38^{\mathrm{b}}$ & $4.43 \pm 1.57^{\mathrm{a}}$ & $4.37 \pm 1.40^{\mathrm{b}}$ \\
E & $3.50 \pm 1.46^{\mathrm{c}}$ & $3.93 \pm 1.53^{\mathrm{c}}$ & $4.50 \pm 1.66^{\mathrm{ab}}$ & $3.70 \pm 1.62^{\mathrm{c}}$ & $4.43 \pm 1.43^{\mathrm{a}}$ & $4.17 \pm 1.42^{\mathrm{b}}$ \\
\hline
\end{tabular}

Means score with different superscript letter in the same column are significantly different at $\mathrm{p}<0.05$. Score 1- Dislike extremely; Score 7- Like extremely

A-Edible tablespoon with $100 \% \mathrm{LPF}$ and $0 \%$ of OMP (control sample)

B- Edible tablespoon with $96 \%$ LPF and 4\% OMP

C- Edible tablespoon with $92 \%$ LPF and $8 \%$ OMP

D- Edible tablespoon with $88 \%$ LPF and $12 \%$ OMP

E- Edible tablespoon with 84\% LPF and 16\% OMP

Morphological structure of edible tablespoon
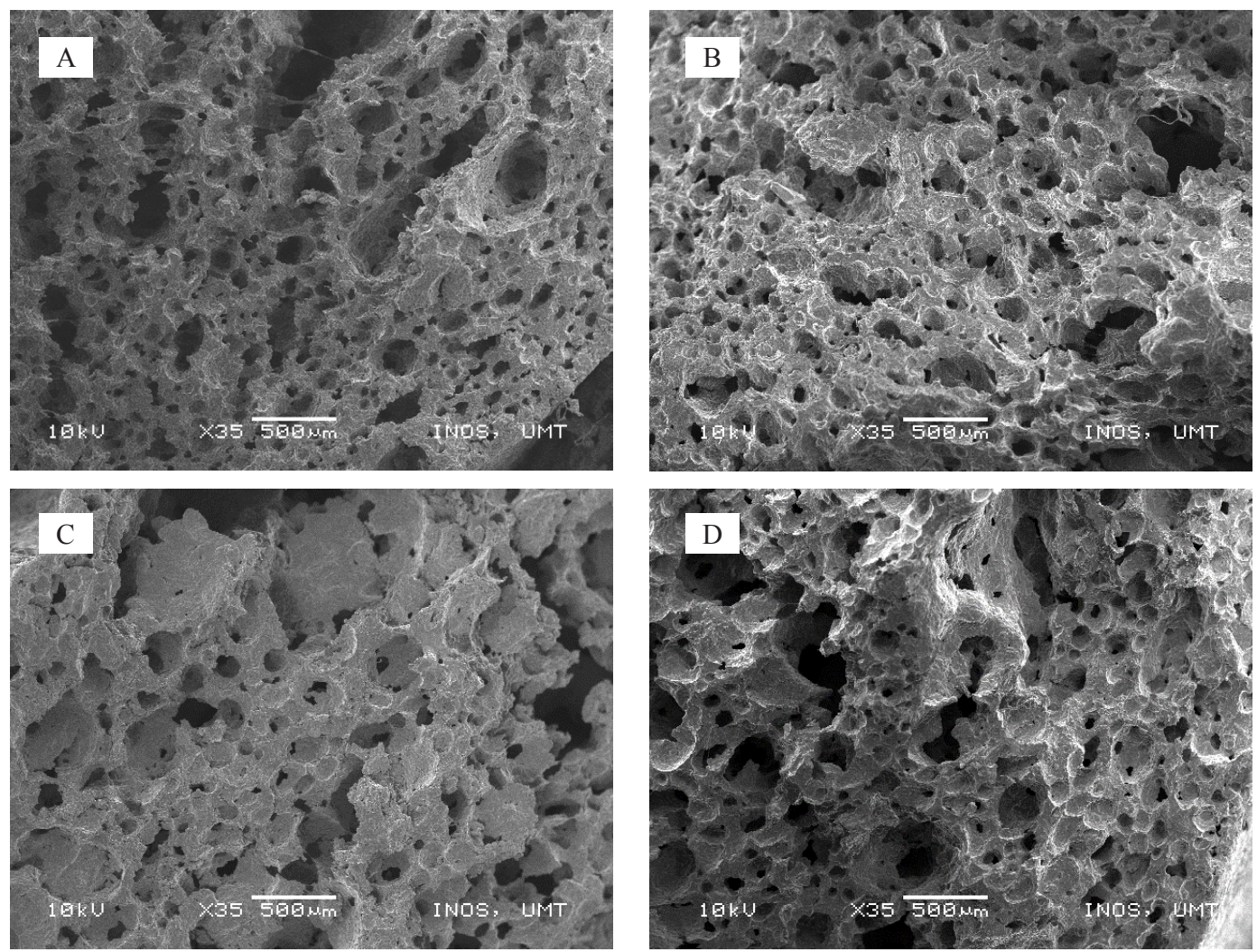


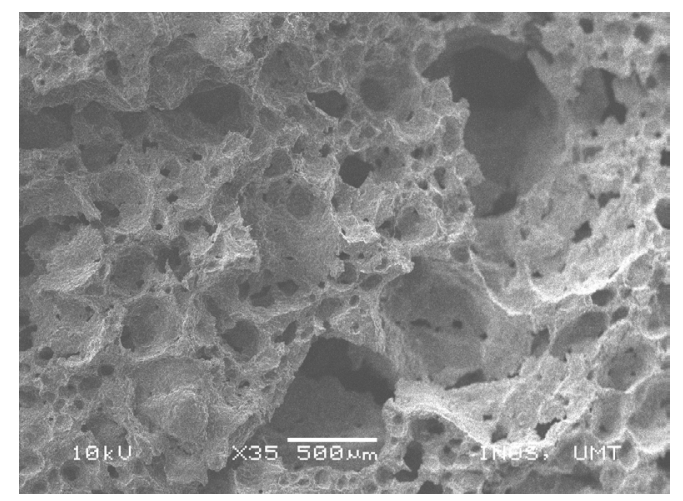

Figure 2: Scanning electron micrograph of edible tablespoons with different ratios of low protein flour (LPF) to oyster mushroom powder (OMP) at $35 \times$ magnification.

A-Edible tablespoon with $100 \%$ LPF and $0 \%$ of OMP (control sample)

B- Edible tablespoon with $96 \%$ LPF and $4 \%$ OMP

C- Edible tablespoon with $92 \%$ LPF and $8 \%$ OMP

D- Edible tablespoon with $88 \%$ LPF and $12 \%$ OMP

E- Edible tablespoon with $84 \%$ LPF and 16\% OMP

\section{Conclusion}

This study suggested that decreasing the percentage of low protein flour and increasing the percentage of oyster mushroom powder lead to an increase of the ash content, fat content and fiber content, $\mathrm{a}^{*}$ and $\mathrm{b}^{*}$ values, hardness, cell diameter of starch granules as well as decrease the $\mathrm{L}^{*}$ value and carbohydrate content of oyster mushroom edible tablespoon. However, moisture, protein and calorie content of edible tablespoon were not significantly affected by different ratios of low protein flour to oyster mushroom powder. Edible tablespoon formulated up to $8 \%$ of oyster mushroom powder can be accepted by panellists and further increasing the oyster mushroom powder in the formulation led to a decrease in the mean score of colour, odour, taste and overall acceptability of edible tablespoon.

\section{Acknowledgements}

The authors were grateful to Universiti Malaysia Terengganu for laboratory equipment and financial support.

\section{References}

Ajayi, O., Obadina, A., Idowu, M., Adegunwa, M., Kajihausa, O., Sanni, L., Tomlins, K. (2015). Effect of packaging materials on the chemical composition and microbiological quality of edible mushroom (Pleurotus ostreatus) grown on cassava peels. Food Science and Nutrition, 3(4), 284-291.

Ahlborn, G. J., Pike, O. A., Hendrix, S. B., Hess, W. M., \& Huber, C. S. (2005). Sensory, mechanical, and microscopic evaluation of staling in low-protein and gluten-free breads. Cereal Chemistry, 82(3), 328-335.

Alobo, A. P. (2001). Effect of sesame seed flour on millet biscuit characteristics. Plant Foods for Human Nutrition, 56(2), 195202.

AOAC, (2000). Official Methods of Analysis. $17^{\text {th }}$ ed. Association of Official Analytical Chemists, Gaithersburg MD.

Ashoush, I. S., \& Gadallah, M. G. E. (2011). Utilization pf Mango Peels and Seed Kernels Powders as Sources of Phytochemicals in Biscuit. Word Journal of Dairy \& Food Sciences, 6 (1), 35-42.

Bello, M., Oluwamukomi, M., \& Enujiugha, V. (2017). Nutrient Composition and Sensory Properties of Biscuit from MushroomWheat Composite Flours. Archives of Current Research International, 9, 1-11.

Cheung, P. C. K. (2013). Mini-review on edible mushrooms as source of dietary fiber: Preparation and health benefits. Food Science and Human Wellness, 2(3-4), 162166.

Croan, S. C. (2004). Conversion of conifer wastes into edible and medicinal mushrooms. Forest Products Journal. 
Dunkwal, V., Jood, S., \& Singh, S. (2007). Physico-chemical properties and sensory evaluation of Pleurotus sajor caju powder as influenced by pre-treatments and drying methods. British Food Journal, 109(9), 749-759.

Farzana, T., \& Mohajan, S. (2015). Effect of incorporation of soy flour to wheat flour on nutritional and sensory quality of biscuits fortified with mushroom. Food Science \& Nutrition, 3(5), 363-369.

Fieschi, M., \& Pretato, U. (2017). Role of compostable tableware in food service and waste management. A life cycle assessment study. Waste Management, 73, 14-25.

Gothandapani, L., Parvathi, K., \& John Kennedy, Z. (1997). Evaluation of Different Methods of Drying on the Quality of Oyster Mushroom (Pleurotus sp). Drying Technology, 15(6-8), 1995-2004.

Herken, E. N., Simsek, S., Ohm, J. B., \& Yurdunuseven, A. (2017). Effect of Mahaleb on Cookie Quality. Journal of Food Processing and Preservation, 41 (4), 1-13.

Majeed, M., Khan, M. U., Owaid, M. N., Khan, M. R., Shariati, M. A., Igor, P., \& Ntsefong, G. N. (2017). Development of Oyster Mushroom Powder and Its Effects on Physicochemical and Rheological Properties of Bakery Products. Journal of Microbiology, Biotechnology and Food Sciences, 6(5), 1221-1227.

Manzi, P., Marconi, S., Aguzzi, A., \& Pizzoferrato, L. (2004). Commercial mushrooms: Nutritional quality and effect of cooking. Food Chemistry, 84(2), 201206.

Maray, A. R. M., Mostafa, M. K., \& ElFakhrany, A. E. D. M. A. (2018). Effect of pretreatments and drying methods on physico-chemical, sensory characteristics and nutritional value of oyster mushroom. Journal of Food Processing and Preservation, 42(1), 1-8.
Martinez-Soto, G., Ocanna-Camacho, R., \& Paredes-Lopez, O. (2001). Effect of pretreatment and drying on the quality of oyster mushroom (Pleurotus osteatus). Drying Technology. 19(3-4), 661-672.

Muyanja, C., Kyambadde, D., \& Namugumya, B. (2014). Effect of Pretreatments and Drying Methods on Chemical Composition and Sensory Evaluation of Osyter Mushroom (Pluerotus Oestreatus) Powder and Soup. Journal of Food Processing and Preservation, 38(1), 457-465.

Ng, S. H., Wan Amir Nizam, W. A., \& Wan Rosli, W. I. (2017). Incorporation of Pleurotus sajor-caju powder in cinnamon biscuit: Study on nutritional, physical, colour and sensorial properties. International Food Research Journal, 24(6), 2442-2450.

Okafor, J. N. C., Okafor, G. I., Ozumba, A. U., \& Elemo, G. N. (2012). Quality characteristics of bread made from wheat and nigerian oyster mushroom (Pleurotus plumonarius) powder. Pakistan Journal of Nutrition, 11(1), 5-10.

Tolera, K. D., \& Abera, S. (2017). Nutritional quality of Oyster Mushroom (Pleurotus ostreatus) as affected by osmotic pretreatments and drying methods. Food Science and Nutrition, 5(5), 989-996.

Verma, A., \& Singh, V. (2017). Formulation and quality evaluation of mushroom (Oyster mushroom) powder fortified potato pudding. Asian Journal of Dairy and Food Research, 36(01), 72-75.

Wakchaure, Mahantesh Shirur, K. Manikandan, L. R. (2010). Development and evaluation of oyster mushroom value added products. Mushroom Research, 19(1): 40-44.

Walde, S. G., Velu, V., Jyothirmayi, T., \& Math, R. G. (2006). Effects of pretreatments and drying methods on dehydration of mushroom. Journal of Food Engineering, 74(1), 108-115. 
Wan Rosli, W., Solihah, M., Aishah, M., Nik Fakurundin, N., \& Mohsin, S. (2011). Colour, texture properties, cooking characteristics and fibre content of chicken patty added with

Oyster mushroom (Pleurotus sajor-caju). International Food Research Journal, 18, 621-627.

Wan Rosli, W. I., Nurhanan, A. R., \& Aishah, M. S. (2012). Effect of partial replacement of wheat flour with oyster mushroom (Pleurotus sajor-caju) powder on nutritional composition and sensory properties of butter biscuit. Sains Malaysiana, 41(12), 1565-1570.
Wan Rosli, W. I., \& Solihah, M. A. (2014). Nutritional composition and sensory properties of oyster mushroom-based patties packed with biodegradable packaging. Sains Malaysiana, 43(1), 65-71.

Wojdyło, A., Figiel, A., Legua, P., Lech, K., Carbonell-Barrachina, Á. A., \& Hernández, F. (2016). Chemical composition, antioxidant capacity, and sensory quality of dried jujube fruits as affected by cultivar and drying method. Food Chemistry, 207, 170-179.

Woody, A. L. (2003). Probing and Three-Point Bend Methods Compared to Sensory Scales as Measurement for Cookie Texture. Master Thesis. University of Tennessee-Knoxville. 